\title{
Medicinal plants with antidiabetic effects (part 2): plant based review
}

\author{
Prof Dr Ali Esmail Al-Snafi \\ Department of Pharmacology, College of Medicine, Thi qar University, Iraq.
}

\begin{abstract}
Many previous reviews showed that medicinal plants possessed antidiabetic effects. These plants included: Achillea santolina, Adiantum capillus-veneris, Agrimony eupatoria, Agropyron repens, Allium species, Aloe vera, Alpinia galangal, Althaea officinalis, Anchusa strigosa, Anthemis nobelis, Arctium lappa, Artemisia campestris, Asparagus officinalis, Avena sativa, Ballota nigra, Benincasa hispida, Brassica species, Bryophyllum calycinum, Caesalpinia crista, Calotropis procera, Canna indica, Capparis spinosa, Capsicum species, Carthamus tinctorius, Carum carvi, Cassia occidentalis and Casuarina equisetifolia. This review was designed to highlight the antidiabetic effects of these medicinal plants as a second part of our previous review.
\end{abstract}

Keywords:- antidiabetic, hypoglycemic, glucose, insulin, medicinal plant, herbs

\section{INTRODUCTION}

In recent years, ethno medicinal studies has received much attention as this brings to light the numerous little known and unknown medicinal virtues especially of plant origin which needs evaluation on modern scientific lines such as phytochemical analysis, pharmacological screening and clinical trials. However, many previous reviews showed that many medicinal plants possessed antidiabetic effects[1-2]. These plants included: Achillea santolina [3], Adiantum capillus-veneris [4], Agrimony eupatoria [5], Agropyron repens [6], Allium species[7], Aloe vera [8], Alpinia galangal [9], Althaea officinalis [10], Anchusa strigosa [11], Anthemis nobelis [12], Arctium lappa [13], Artemisia campestris [14], Asparagus officinalis [15], Avena sativa [16], Ballota nigra [17], Benincasa hispida [18], Brassica species [19], Bryophyllum calycinum []20], Caesalpinia crista [21], Calotropis procera [22], Canna indica [23], Capparis spinosa [24], Capsicum species [25], Carthamus tinctorius [26], Carum carvi [27], Cassia occidentalis [28] and Casuarina equisetifolia [29]. This review was designed to highlight the antidiabetic effects of these medicinal plants as a second part of our previous review[1].

\section{MEDICINAL PLANTS WITH ANTIDIABETIC EFFECTS}

Cicer arietinum

It was reported that the seeds reduced postprandial plasma glucose and were useful in the treatment of diabetes. The antihyperglycaemic activity of petroleum ether extract of Cicer arietinum (PEECA) seeds was evaluated at three different doses i.e. 100, 200 and $400 \mathrm{mg} / \mathrm{kg}$ po in alloxan $(70 \mathrm{mg} / \mathrm{kg}$ iv) induced diabetic mice. In both acute and subacute studies serum glucose level (SGL) was measured. The change in body weight was noted during subacute study. Oral glucose tolerance test (OGTT) was performed in both diabetic and non-diabetic mice previously loaded with $(2.5 \mathrm{~g} / \mathrm{kg}$ po $)$ glucose. Glyburide $(10 \mathrm{mg} / \mathrm{kg})$ was used as a standard drug. The maximum reduction in SGL was observed in PEECA (400 mg/kg) group at $6 \mathrm{~h}(137.17 \mathrm{mg} / \mathrm{dl})$ in acute study and on $21^{\text {st }}$ day $(217.79 \mathrm{mg} / \mathrm{dl})$ in subacute study respectively. In glyburide treated mice the maximum reduction in SGL was observed at $6 \mathrm{~h}(194.97 \mathrm{mg} / \mathrm{dl})$ and on $21^{\text {st }}$ day $(267.40 \mathrm{mg} / \mathrm{dl})$ respectively. PEECA $(400 \mathrm{mg} / \mathrm{kg})$ and glyburide $(10 \mathrm{mg} / \mathrm{kg})$ prevented loss of body weight in diabetic mice. OGTT showed increased glucose threshold in nondiabetic and diabetic mice. Accordingly, PEECA showed antihyperglycaemic activity comparable with glyburide [30].

\section{Cichorium intybus}

Ischemic manifestations and cerebral dysfunction have been demonstrated in diabetes. Otherwise, the impairment in the glycemic control is the basic mechanism causing inhibition of neuronal activity. Cerebral extract from alloxan diabetic rats significantly inhibited the brain AChE activity of normal animals, indicating the presence of an inhibiting factor in the cerebrum of diabetic rats. Cichorium intybus when fed for 10 days offered neuroprotection in diabetic rats by stimulating AChE activity [31-32].

The hypoglycemic and hypolipidemic properties of an ethanolic extract of Cichorium intybus (CIE) was studied in rats. Male Sprague-Dawley rats aged 9 weeks were administered with streptozotocin (STZ, $50 \mathrm{mg} / \mathrm{kg}$ ) intraperitoneally to induce experimental diabetes. The Cichorium intybus whole plant (CIE) was exhaustively extracted with $80 \%$ ethanol. Hypoglycemic effects of CIE were observed in an oral glucose tolerance test (OGTT). A dose of $125 \mathrm{mg}$ of plant extract/kg bw exhibited the most potent hypoglycemic effect. 
Moreover, daily administration of CIE $(125 \mathrm{mg} / \mathrm{kg})$ for 14 days to diabetic rats attenuated serum glucose by $20 \%$, triglycerides by $91 \%$ and total cholesterol by $16 \%$. However, there was no change in serum insulin levels, which ruled out the possibility that CIE induced insulin secretion from pancreatic beta-cells. In addition, hepatic glucose-6-phosphatase activity (Glc-6-Pase) was markedly reduced by CIE when compared to the control group. The authors concluded that the reduction in the hepatic Glc-6-Pase activity could decrease hepatic glucose production, which in turn results in lower concentration of blood glucose in CIE-treated diabetic rats [33].

The effect of Cichorium intybus methanolic extract (CME) on glucose transport and adipocyte differentiation in 3T3-L1 cells was investigated by studying the radiolabelled glucose uptake and lipid accumulation assays. By performing detannification (CME/DT), the role of tannins present in CME on both the activitie`s was evaluated. CME and CME/DT exhibited significant glucose uptake in 3T3-L1 adipocytes with a dose-dependent response. CME inhibited the differentiation of 3T3-L1 preadipocytes but failed to show glucose uptake in inhibitor treated cells. The activity exhibited by CME/DT is exactly vice versa to CME. Furthermore, the findings from PTP1B inhibition assay, mRNA and protein expression analysis revealed the unique behavior of CME and CME/DT. Accordingly, the activities possessed by Cichorium intybus are highly desirable for the treatment of NIDDM because it reduces blood glucose levels without inducing adipogenesis in 3T3-L1 adipocytes [34].

The direct action of soluble fibers (chicory water-soluble extract and inulin) was investigated on the intestinal absorption of glucose in gut perfused rats. After equilibrium, both jejunal and ileal segments were simultaneously perfused with an isotonic electrolyte solution ( $\mathrm{pH} 7.4)$ containing glucose (10 mmol/l) and chicory water-soluble extract (chicory extract) or inulin $(10 \mathrm{~g} / \mathrm{l})$. Each test or control solution was perfused in random sequence, with perfusion times of $30 \mathrm{~min}$. Chicory extract or inulin in the perfusate $(10 \mathrm{~g} / \mathrm{l})$ inhibited the absorption of glucose from jejunum $(\mathrm{P}<0.05)$. The observed changes in glucose and water absorption caused by chicory extract or inulin were reversible after switching to a fiber free perfusate. Additionally, net water absorption changed to secretion upon addition of chicory extract or inulin. The authors concluded that the reduction in intestinal absorption of glucose observed after perfusion of chicory extract or inulin may be caused by viscosity-related increases in mucosal unstirred layer thickness [35].

In vitro experiments were designed to compare the effects of two hydroxycinnamic acids, caffeic and ferulic acids, to those obtained with a natural chicoric acid extract (NCRAE) $(50$ and $100 \mu \mathrm{g} / \mathrm{ml})$ on the three major tissues implicated in glycemic regulation (pancreas, muscle and liver). In vivo experiments were performed in Wistar rats submitted to a daily intraperitoneal injection of natural chicoric acid extract NCRAE $(3,15$ or $30 \mathrm{mg} / \mathrm{kg}$ ) for 4 days. On the fourth day, an intraperitoneal glucose tolerance test (IPGTT; $1 \mathrm{~g} / \mathrm{kg}$ ) was carried out. Results showed that the three compounds used were able each to induce an original response. Caffeic acid mainly promoted a decrease in hepatic glycogenolysis. Ferulic acid elicited a clear increase of insulin release and a reduction of hepatic glycogenolysis. However, this compound induced an inhibition of muscle glucose uptake. NCRAE provoked an increase of insulin release and glucose uptake without any effect on hepatic glycogenolysis. None of these compounds implicated hepatic glucose 6-phosphatase in contrast to chlorogenic acid, known as an inhibitor of glucose 6-phosphatase and which is able to decrease glucose output from hepatocytes. In vivo experiments bring evidence that 4 daily ip administrations of NCRAE improve ip glucose tolerance in a dose-dependent manner and mainly via an insulin sensitizing effect [36].

The effects of a high-fructose diet supplemented with rutin and a chicory (Cichorium intybus L.) seed extract rich in caffeoylquinic acids (CQA) was tested on gut physiology and the development of disorders related to metabolic syndrome. A 28-days experiment was conducted on 32 young male Wistar rats. In comparison with control rats fed a standard corn starch diet (group C), the experimental group (group E) was fed a diet with an increased content of cholesterol and fructose (to $1 \%$ and $66 \%$ of the diet, respectively), as well as with oxidized soybean oil. Rats from the other two experimental groups were administered the same diet as group E during the first 2 wks of feeding, whereas at the beginning of the last 2 wks, the diet was enriched with rutin (group ER) or the CQA-rich ethanol extract from chicory seeds (9.6\% of CQA, group EC), so the amount of added phenolics was equal in both dietary groups $(0.15 \%)$. The diet administered in group E caused hyperglycemia and increased blood serum atherogenicity in rats, but did not induce other manifestations of the metabolic syndrome, i.e., dyslipidemia and oxidative stress. Additionally, it affected gut physiology through increasing mucosal sucrase activity and disturbing fermentative processes in the cecum, such as the production of short-chain fatty acids and the activity of microbial enzymes. Similarly to rutin, the dietary addition of the chicory seed extract improved glycemia, which was comparable to that determined in group C. In addition, the extract was found to decrease the atherogenic index to the level observed in group $\mathrm{C}$ and to increase blood antioxidant status. Both dietary supplements reduced the content of thiobarbituric acid-reactive substances in kidney and heart tissue when compared with group E [37].

The effects of different chicory extracts on the blood glucose, total cholesterol (TC) and triglycerides (TG) was studied in hyperglycemic mouse model. It was found that the chicory alcohol soluble extract can decrease the blood glucose, TC and TG, which is more effective than the chicory alcohol deposit extracts [38].Five intraperitoneal injection of cerulean $(50 \mu \mathrm{g} / \mathrm{kg}$ at $1 \mathrm{~h}$ intervals $)$ in mice resulted in acute pancreatitis, 
which was characterized by edema, neutrophil infiltration, as well as increases in the serum levels of amylase and lipase in comparison to normal mice. Different doses of Cichorium intybus root (CRE) and aerial parts hydroalcoholic extract (CAPE) orally $(50,100,200 \mathrm{mg} / \mathrm{kg})$ and intraperitoneally $(50,100,200 \mathrm{mg} / \mathrm{kg}) \mathrm{were}$ administrated 1.0 and $0.5 \mathrm{~h}$ respectively before pancreatitis induction on separate groups of male mice $(\mathrm{n}=6)$. Control groups treated with normal saline $(5 \mathrm{ml} / \mathrm{kg})$ similarly. Both extracts in greater test doses $(100 \mathrm{mg} / \mathrm{kg}$ and $200 \mathrm{mg} / \mathrm{kg}$, ip) were effective to decrease amylase (23-36\%) and lipase (27-35\%) levels. In oral route, the dose of $200 \mathrm{mg} / \mathrm{kg}$ showed a significant decrease in levels of amylase (16\%) and lipase (24\%) activity while the greatest dose $(200 \mathrm{mg} / \mathrm{kg}$, ip) was only effective to diminish inflammatory features like edema and leukocyte infiltration in pancreatitis tissue $(\mathrm{P}<0.01)$ [39].

\section{Cistanche tubulosa}

The effects of Cistanche tubulosa on glucose homeostasis and serum lipids were studied in male mice model of type 2 diabetes. Different doses of Cistanche tubulosa (equivalent to 120.9, 72.6 or $24.2 \mathrm{mg}$ verbascoside $/ \mathrm{kg}$ ) were administered orally once daily for 45 days to male $\mathrm{db} / \mathrm{db}$ mice. Cistanche tubulosa significantly suppressed the elevated fasting blood glucose and postprandial blood glucose levels, improved insulin resistance and dyslipidemia, and suppressed body weight loss. However, Cistanche tubulosa did not significantly affect serum insulin levels or hepatic and muscle glycogen levels [40]. Acylated phenylethanoid glycosides, echinacoside and acteoside, the principal constituents in the stems of Cistanche tubulosa, inhibited the increased postprandial blood glucose levels in starch-loaded mice at doses of $250-500 \mathrm{mg} / \mathrm{kg}$ po. They also significantly improved glucose tolerance in starch-loaded mice after 2 weeks of continuous administration at doses of 125 and/or $250 \mathrm{mg} / \mathrm{kg} /$ day po without producing significant changes in body weight or increasing food intake. In addition, several constituents from Cistanche tubulosa, including echinacoside $\left(\mathrm{IC}_{50}=3.1 \mu \mathrm{M}\right)$, acteoside $(1.2 \mu \mathrm{M})$, isoacteoside $(4.6 \mu \mathrm{M})$, 2'-acetylacteoside $(0.071 \mu \mathrm{M})$, tubulosides A $(5,8.8 \mu \mathrm{M}), \mathrm{B}(9,4.0 \mu \mathrm{M})$, syringalide A 3-O- $\alpha$-L-rhamnopyranoside $(10,1.1 \mu \mathrm{M})$, campneoside I $(13,0.53 \mu \mathrm{M})$, and kankanoside $\mathrm{J} 1(14,9.3 \mu \mathrm{M})$, demonstrated potent rat lens aldose reductase inhibitory activity. The potency of 2 '-acetylacteoside was similar to that of epalrestat $(0.072 \mu \mathrm{M})$, a clinical aldose reductase inhibitor [41].

\section{Citrullus colocynthis}

The efficacy of Citrullus colocynthis (L.) Schrad fruit in 2 months clinical trial was conducted in 50 type II diabetic patients. Two groups of 25 each under standard antidiabetic therapy, received 100 mg Citrullus colocynthis fruit capsules or placebos three times a day, respectively. The patients were visited monthly and glycosylated hemoglobin (HbA1c), fasting blood glucose, total cholesterol, LDL, HDL, triglyceride, aspartate transaminase, alanine transaminase, alkaline phosphatase, urea and creatinine levels were determined at the beginning and after 2 months. The results showed a significant decrease in HbAlc and fasting blood glucose levels in $C$. colocynthis treated patients. Other serological parameters levels in both groups did not change significantly. No notable gastrointestinal side effect was observed in either group [42-43].

The direct in vitro effects of several distinct Citrullus colocynthis seed extracts was evaluated in glucosestimulated insulin release from pancreatic islets isolated from rats. Six extracts were tested, a crude aqueous, defatted aqueous, ethyl acetate, $\mathrm{H}_{2} \mathrm{O}$-methanol, n-butanol extract and an extract containing a mixture of the major component (fraction A) identified by gel chromatography in the ethyl acetate, n-butanol and $\mathrm{H}_{2} \mathrm{O}$ methanol extracts. The majority of extracts exhibited a positive insulinotropic action when tested in the presence of $8.3 \mathrm{mM}$ D-glucose [44]. Citrullus colocynthis possessed antidiabetic effect in rats at the dose of 50 and $100 \mathrm{mg} / \mathrm{kg}$ bw for 28 days. Haematological and biochemical estimations were done at the end of experiment. Rats were then sacrificed and histopathological examinations were carried out. The results obtained showed that Citrullus colocynthis is safe for use as an antidiabetic remedy [45].

The effect of root of Citrullus colocynthis on the biochemical parameters of normal and alloxaninduced diabetic was investigated in rats. Aqueous extract of roots of Citrullus colocynthis showed significant reduction in blood sugar level $(58.70 \%)$ when compared with chloroform $(34.72 \%)$ and ethanol extracts $(36.60 \%)(\mathrm{p}<0.01)$. The aqueous extracts showed improvement in parameters like body weight, serum creatinine, serum urea and serum protein as well as lipid profile and also restored the serum level of total and conjugated bilirubin, serum glutamate oxaloacetate transaminase, serum glutamate pyruvate transminase and alkaline phosphatase [46].

The antidiabetic effect of Citrullus colocynthis on liver hexokinase and gluconeogenic enzymes such as glucose-6-phosphatase and fructose 1, 6-bisphosphatase was investigated in control and alloxan-diabetic rats. Oral administration of leaf suspension of Citrullus colocynthis (250 and 500mg $/ \mathrm{kg}$ body weight) for 60 days resulted in momentous reduction in blood glucose (from $381 \pm 34$ to $105 \pm 35 \mathrm{mg} / \mathrm{dl}$ ), glycosylated hemoglobin, a decrease in the activities of glucose- 6 phosphatase and fructose 1, 6-bisphosphatase, and an increase in the activity of liver hexokinase. These findings further support the antidiabetic effect of Citrullus colocynthis [47]. 
A double-blind randomized placebo-controlled clinical trial using a parallel design was carried out to examine the safety and efficacy of Citrullus colocynthis topical formulation in patients with painful diabetic neuropathy. Sixty patients with painful diabetic polyneuropathy (PDPN) were randomly allocated to receive the topical formulation of Citrullus colocynthis (1:1 allocation ratio) or placebo for three months. The patients were evaluated before and after the intervention in terms of Neuropathic Pain Scale, electrodiagnostic findings, World Health Organization BREF quality of life scores and reported adverse events. The mean change in pain score was significantly higher in the Citrullus colocynthis group 3.89 than in the placebo group $2.28(\mathrm{P}<0.001)$. The mean changes in nerve conduction velocity of the tibial nerve, distal latency of the superficial peroneal nerve and sural nerve, as well as sensory amplitude of the sural nerve in the intervention group were significantly higher than in the placebo group $(\mathrm{P}<0.001)$. No significant differences were observed between the mean changes in other nerve conduction values. World Health Organization BREF quality of life scores, only showed significant improvement of the physical domain [48].

The effect of Citrullus colocynthis pulp extract on the structure of the liver was tested in diabetic rats at both light and scanning electron microscopic levels. Diabetes caused degenerative alterations in the form of disorganization of the hepatic cords, cytoplasmic vacuolization and pyknosis of the nuclei of hepatocytes and inflammatory cell infiltration. Scanning electron microscope examination of these livers revealed numerous lipid droplets within hepatocytes, damaged blood sinusoids and hemorrhage of erythrocytes between hepatocytes and inside Disse's spaces. The liver of Citrullus colocynthis-treated rats revealed minor histological changes versus the control animals [49].

\section{Citrus species}

To study the hypoglycemic effect of hexane extract of Citrus limon peel, diabetes was induced in rats by a single intraperitonial injection of alloxan $(140 \mathrm{mg} / \mathrm{kg} \mathrm{bw})$. Hexane extract $(200 \mathrm{mg} / \mathrm{kg}$ bw) of Citrus limon peel was administered orally, while metformine hydrochloride $(175 \mathrm{mg} / \mathrm{kg} \mathrm{bw})$ was used as a standard drug. The results showed that hexane extract exerted significant hypoglycemic activity and the activity of extract was comparable to that of standard drug [50].

The effect of oral treatment with citrus peel extracts on wound repair of the skin was studied in diabetic rats. The extracts were estimated for vitamin $\mathrm{C}$ and total carotenoid contents prior to animal study. Diabetes mellitus was induced in rats by intraperitoneal injection of a single dose of streptozotocin (STZ, $75 \mathrm{mg} / \mathrm{kg} \mathrm{bw}$ ). One week after diabetes induction, full thickness excision wounds were made in hyperglycemic rats. The different test groups were treated with different citrus peel extracts orally at the dose of $400 \mathrm{mg} / \mathrm{kg}$ bw daily for 12 days. The blood glucose, body weight and rate of wound closure of each rat were measured every $3^{\text {rd }}$ day during the experimental period. At the end of experiment, granular tissues of wounds were removed and estimated for hydroxylproline and total protein content. The results showed significant reduction in blood glucose and time to wound closure. Tissue growth and collagen synthesis were significantly higher as determined by total protein and hydroxylproline content [51].

Measurements of the effects of Citrus medica cv Diamante peel extract on the mouse insulinoma MIN6 $\beta$-cells indicated that it exerted direct stimulatory effects on the exocytotic release of insulin in a concentration-dependent manner. Citrus medica cv Diamante peel extract reduced plasma glucose concentration in mice [52].

The antidiabetic and hypolipidemic activity of petroleum ether extract of Citrus medica seeds was studied in streptozotocin (STZ) induced diabetic model in rats. Seed extract was given as (200 and $400 \mathrm{mg} / \mathrm{kg}$, po.) The petroleum ether extract of Citrus medica seeds induced significant reduction $(\mathrm{p}<0.05)$ of fasting blood glucose, serum cholesterol, serum triglycerides, LDL and VLDL in dose dependent manner after 15 days of drug administration. However, $200 \mathrm{mg} / \mathrm{kg} /$ day seed extract for 15 days was not showing any change in HDL level, while $400 \mathrm{mg} / \mathrm{kg} /$ day dose significantly increased HDL level in diabetic rats [53].

In vivo hypoglycemic, and antidiabetic activity of Citrus medica L. var. Sarcodactylis were confired in Sprague-Dawley-SPF rats and Wistar DIO rats. Insulin secretagogue effect of Citrus medica L. var. Sarcodactylis Hort fruits was confirmed by kinetic analysis on the hypoglycemic patterns of the intraperitoneal glucose tolerance and the insulin-glucose tolerance tests [54].

The antihyperglycemic activity of methanol extract of Citrus limetta fruit peel (MECL) was evaluated in streptozotocin-induced (STZ; $65 \mathrm{mg} / \mathrm{kg}$ bw) diabetic rats. Three days after STZ induction, diabetic rats received MECL orally at 200 and $400 \mathrm{mg} / \mathrm{kg}$ bw daily for 15 days. Glibenclamide $(0.5 \mathrm{mg} / \mathrm{kg}$ po $)$ was used as reference drug. Blood glucose levels were measured on $0,4^{\text {th }}, 8^{\text {th }}$, and $15^{\text {th }}$ days of study. Serum biochemical parameters namely, SGOT, SGPT and ALP were also estimated. The TBARS and GSH levels of pancreas, kidney, and liver were determined. MECL significantly $(\mathrm{P}<0.001)$ and dose dependently normalized blood glucose levels and serum biochemical parameters, decreased lipid peroxidation, and recovered GSH as compared to those of STZ control [55].

The inhibitory effect of the aqueous Citrus limetta peel extract on the metabolism of carbohydrates was studied. The extract inhibited primarily the enzyme $\alpha$-amylase by $49.6 \%$ at a concentration of $20 \mathrm{mg} / \mathrm{ml}$ and to a 
lesser extent the enzyme $\alpha$-glucosidase with an inhibition of $28.2 \%$ at the same concentration. This inhibition was likely due to the high polyphenol content in the Citrus limetta peel (19.1 mg GAE/g). Antioxidant activity of the Citrus limetta peel demonstrated dose-dependent antioxidant activity, varying from $6.5 \%$ at $1.125 \mathrm{mg} / \mathrm{ml}$ to $42.5 \%$ at $20 \mathrm{mg} / \mathrm{ml}$. The results showed that these polyphenolic compounds having both antihyperglycemic and antioxidant activities [56].

The anti-diabetic potential of orange peel and juice was attributed to anti peroxidation, inhibition of $\alpha$ amylase enzyme activity responsible for the conversion of complex carbohydrates to glucose, increased hepatic glycogen content, stimulation of insulin secretion, and repair of secretory defects of pancreatic $\beta$-cells [57-58]. The effects of four different concentrations of peel extract from Citrus sinensis (CS) were investigated in male mice, the results revealed that they exerted glucose lowering and antiperoxidative activities. In a separate experiment their potential was evaluated with respect to the regulation of alloxan induced diabetes mellitus. While a single dose of alloxan $(120 \mathrm{mg} / \mathrm{kg})$ increased the serum levels of glucose and alpha-amylase activity, rate of water consumption and lipid peroxidation (LPO) in hepatic, cardiac and renal tissues with a parallel decrease in serum insulin level, administration of $25 \mathrm{mg} / \mathrm{kg}$ of CS was found to normalize all the adverse changes induced by alloxan, revealing the antidiabetic and anti peroxidative potential of tested fruit peel extracts [59].

\section{Clerodendrum inerme}

The anti-diabetic activity of Clerodendrum inerme was evaluated using in vivo streptozotocin-induced diabetes in mice, and in vitro studies. The leaves of $C$. inerme were extracted in petroleum ether, methanol followed by aqueous solvent. Methanolic extract of leaves of Clerodendrum inerme at $200 \mathrm{mg} / \mathrm{kg}$ showed a very significant and progressive reduction in glucose level [60-61].

\section{Clitoria ternatea}

The hypoglycemic effects of methanol, water, petroleum ether and chloroform extract of Clitoria ternatea leaves were evaluated in Streptozotocin induced diabetic rats for acute and subacute effects. The extract of Clitoria ternatea ( 200 and $400 \mathrm{mg} / \mathrm{kg}$ ) significantly reduced blood glucose level in Streptozotocin induced diabetic rats. $400 \mathrm{mg} / \mathrm{kg}$ possessed significant hypoglycemic effect, $200 \mathrm{mg} / \mathrm{kg}$ also decreased glucose level but not as $400 \mathrm{mg} / \mathrm{kg}$. The result of acute effect of the methanol extract, showed that $200 \mathrm{and} 400 \mathrm{mg} / \mathrm{kg}$ exerted a very similar effect, but at the initial stage at the $30 \mathrm{~min}, 200 \mathrm{mg} / \mathrm{kg}$ showed a fine decrease in blood glucose level. Subacute activity showed that on the long term use of extract the dose $200 \mathrm{mg} / \mathrm{kg}$ is much better to control the blood glucose level than the $400 \mathrm{mg} / \mathrm{kg}$ dose [62-63].

The hypoglycemic effects of methanol extract of Clitoria ternatea leaves (200 and $400 \mathrm{mg} / \mathrm{kg}$ ) was investigated in alloxan induced diabetic rats. The extract of Clitoria ternatea significantly $(\mathrm{P}<0.001)$ reduced blood glucose level in alloxan induced diabetic rats twelve hours after administration [64].

The hypoglycemic effects of the aqueous extract of Clitoria ternatea leaves and flowers ( $50-500 \mathrm{mg} / \mathrm{kg}$ ) were investigated in alloxan-induced diabetes in rats. The aqueous extracts of Clitoria ternatea leaves and flowers $(400 \mathrm{mg} / \mathrm{kg} \mathrm{bw})$ significantly $(\mathrm{P}<0.05)$ reduced serum glucose, glycosylated hemoglobin and the activities of gluconeogenic enzyme, glucose-6- phosphatase, but increased serum insulin, liver and skeletal muscle glycogen and the activity of the glycolytic enzyme, glucokinase. For all the biochemical tests performed, the leaf extract-treated rat showed essentially the same profile as those treated with the flower extract [65-66].

The effect of combined leaf extracts of Clitoria ternatea (CTL) and Trichosanthes dioica (TDL) was evaluated on the streptozotocin (STZ) induced diabetic Wistar rats. The results revealed that the combined extracts significantly decreased $(\mathrm{p}<0.05)$ serum glucose after the 28-days treatment [67].

Encephalopathy is a major complication in juvenile diabetes mellitus which cripples the potential physiomorphological growth and development in early childhood. The alcoholic extract of roots of Clitoria ternatea was evaluated in preventing the possible complications related to brain hippocampal area CA3 and pancreatic tissue in juvenile diabetic rat experimental models. The diabetes was induced in 22 days (post natal) Wistar rats by giving intra peritoneal injection of Streptozotocin at a dose of $60 \mathrm{mg} / \mathrm{kg}$ body weight. After the confirmation of diabetic state, the treatment with oral administration of alcoholic root extract of Clitoria ternate a a dose of $100 \mathrm{mg} / \mathrm{kg} \mathrm{bw} /$ day, was started immediately and continued for one month duration. At the end of 30 days treatment, the animals were sacrified, brain and pancreatic tissues were collected for gross and histological studies. On microscopy the brain tissue showed homogenous architecture, the hippocampal CA3 region neurons showed gross viable changes in the cell morphology. On the other hand, pancreatic tissue showed reduction in the cell with hypertrophy along with relatively less inflammatory changes in the islet cells of Langerhans of animals treated by alcoholic extract of roots of Clitoria ternatea. The authors concluded that alcoholic root extract of herb Clitoria ternatea significantly prevented the complications related to brain hippocampal area CA3 and pancreatic tissue in juvenile diabetic rat experimental models [68].

The effect of alcoholic root extract of Clitoria ternatea on the neurons of frontal cortex and dentate gyrus was studied in young diabetic rats. The diabetes was induced in 22 days (postnatal) Wistar rats by giving 
intraperitoneal injection of Streptozotocin at a dose of $60 \mathrm{mg} / \mathrm{kg}$ body weight. Daily single oral treatment of 100 $\mathrm{mg} / \mathrm{kg}$ bw of alcoholic root extract of Clitoria ternatea was started and continued for a month. At the end of treatment, the animals were sacrificed and brain tissue was subjected to histopathological studies. The preventive effect of the alcoholic root extract of Clitoria ternatea was confirmed by significant increase of viable neurons and the significant effect on the morphology of neurons of frontal cortex and dentate gyrus [69].

The inhibitory effect of the aqueous extract of Clitoria ternatea flower (CTE) was studied on fructoseinduced formation of advanced glycation end products (AGEs) and protein oxidation. Inhibition of AGE formation is the imperative approach for alleviating diabetic complications. The various concentrations of CTE were incubated with BSA and fructose at $37^{\circ} \mathrm{C}$ for 28 days. The formation of fluorescent AGEs, the level of fructosamine, protein carbonyl content, and thiol group were measured. The in vitro antioxidant activity was measured by the 1,1-diphenyl 2-picrylhydrazyl (DPPH) scavenging activity, trolox equivalent antioxidant capacity (TEAC), ferric reducing antioxidant power (FRAP), hydroxyl radical scavenging activity (HRSA), superoxide radical scavenging activity (SRSA), and ferrous ion chelating power (FICP). The results demonstrated that CTE $(0.25-1.00 \mathrm{mg} / \mathrm{ml})$ significantly inhibited the formation of AGEs in a concentrationdependent manner. CTE also markedly reduced the levels of fructosamine and the oxidation of protein by decreasing protein carbonyl content and preventing free thiol depletion. In the DPPH radical scavenging activity and SRSA, CTE had the $\mathrm{IC}_{50}$ values of $0.47 \pm 0.01 \mathrm{mg} / \mathrm{ml}$ and $0.58 \pm 0.04 \mathrm{mg} / \mathrm{ml}$ respectively. Furthermore, the FRAP and TEAC values of CTE were $0.38 \pm 0.01 \mathrm{mmol} \mathrm{FeSO} 4$ equivalents $/ \mathrm{mg}$ dried extract and $0.17 \pm 0.01 \mathrm{mg}$ trolox equivalents/mg dried extract. However, CTE showed weak scavenging activity on hydroxyl radical and a weak antioxidant iron chelator. As conclusion, the results showed that CTE has strong antiglycation and antioxidant properties and might have therapeutic potentials in the prevention of AGE-mediated diabetic complications [70].

The pancreatic regeneration potential of diferent fractions of the ethanol extract of the aerial parts of Clitoria ternatea L. was studied. The antidiabetic and antihyperlipidemic potential was evaluated in streptozotocin-induced diabetic rats and correlated with its in vivo and in vitro antioxidant activity. The extract and its fractions were initially screened for acute and sub-chronic antidiabetic activity in the dose range of 100$200 \mathrm{mg} / \mathrm{kg}$. The most potent extract and fractions were further evaluated for pancreatic $\beta$-cells regeneration activity along with antioxidant and antihyperlipidemic activity. The most significant pancreatic regeneration activity, antidiabetic and antihyperlipidemic activity was shown by ethanol extract and butanol soluble fraction at a dose level of $200 \mathrm{mg} / \mathrm{kg}$ [71].

\section{Coriandrum sativum}

Administration of coriander seeds (5g/day) to NIDDM patients for 60 days significantly decreased lipid peroxidation, protein oxidation, decreased activity of erythrocyte catalase (CAT), increased serum $\beta$ carotene, vitamin A, E and C in NIDDM diabetics. The treatment was also increased the activity of erythrocyte antioxidant enzyme i.e. glutathione-S-transferase (GST) and reduced glutathione content (GSH) in the treated diabetics [72].

The hypoglycemic effect of Coriandrum sativum was studied clinically in patients with type-2 diabetes mellitus. After assaying fasting plasma and urinary glucose, 10 patients of type-2 diabetes mellitus with no previous medication, 10 patients of type-2 diabetes mellitus taking oral hypoglycemic agents with history of inadequate control and six control subjects were given low $(2.5 \mathrm{~g}$ tid $)$ and high $(4.5 \mathrm{~g}$ tid $)$ doses of aqueous and alcoholic extracts of Coriandrum sativum for 14 days. On $15^{\text {th }}$ day, blood and urine samples were taken for glucose estimation. Coriandrum sativum has significant hypoglycemic activity in high dose and can be successfully combined with oral hypoglycemic agents in type-2 diabetic patients whose diabetes was not controlled by oral hypoglycemic drug alone [73-74].

The hypoglycemic activity of methanolic extracts of leaves of Coriandrum sativum was evaluated in rats. The methanolic extract showed significant dose dependant decrease in blood glucose level at a dose of 200 and $400 \mathrm{mg} / \mathrm{kg}$. It also decreased the lipid parameters such as total cholesterol, LDL, HDL, VLDL and TG when compared with diabetic control. SGOT and SGPT were reduced dose dependently [75].

Coriander incorporated into the diet $(62.5 \mathrm{~g} / \mathrm{kg})$ and drinking water $(2.5 \mathrm{~g} / \mathrm{l}$, prepared by $15 \mathrm{~min}$ decoction) reduced hyperglycaemia of streptozotocin-diabetic mice. An aqueous extract of coriander $(1 \mathrm{mg} / \mathrm{ml})$ increased 2-deoxyglucose transport (1.6-fold), glucose oxidation (1.4-fold) and incorporation of glucose into glycogen of isolated murine abdominal muscle (1.7-fold) comparable with $10^{-8} \mathrm{M}$-insulin. In acute 20 min tests, $0.25-10 \mathrm{mg} / \mathrm{ml}$ aqueous extract of coriander evoked a stepwise 1.3-5.7-fold stimulation of insulin secretion from a clonal B-cell line. This effect was abolished by $0.5 \mathrm{mM}$-diazoxide. The effect of extract was potentiated by $16.7 \mathrm{mM}$-glucose and $10 \mathrm{mM}$-L-alanine but not by $1 \mathrm{mM}$-3-isobutyl-1-methylxanthine. Insulin secretion by hyperpolarized B-cells $(16.7 \mathrm{mM}$-glucose, $25 \mathrm{mM}-\mathrm{KCl})$ was further enhanced by the presence of extract. Activity of the extract was found to be heat stable, acetone soluble and unaltered by overnight exposure to acid $(0.1 \mathrm{M}-\mathrm{HCl})$ or dialysis to remove components with molecular mass<2000 Da. Activity was reduced by overnight exposure to alkali $(0.1 \mathrm{M}-\mathrm{NaOH})$. Sequential extraction with solvents revealed insulin-releasing 
activity in hexane and water fractions indicating a possible cumulative effect of more than one extract constituent [76].

Coriandrum sativum (CS) supplementation (1\% and 3\% w/w) to high fat diet (HFD) mice (for 12 weeks) significantly prevented HFD induced increment in body weight gain, food intake, feed efficiency, fasting blood glucose, plasma insulin, fasting insulin resistance index (FIRI), plasma and hepatic triglyceride (TG), total cholesterol (TC), plasma free fatty acid (FFA), adipocyte diameter and surface area along with decrement in adipocyte number. These set of changes were comparable to the rosiglitazone $(0.05 \%)$ supplemented HFD fed mice [77].

The ethanol extract of Coriandrum sativum seeds was investigated for its effects on insulin release from the pancreatic beta cells in streptozotocin-induced diabetic rats. Pancreatic sections of 5 microm were processed for examination of insulin-releasing activity using an immunocytochemistry method. The results showed that administration of the ethanol extract (200 and $250 \mathrm{mg} / \mathrm{kg}$, ip) exhibited a significant reduction in serum glucose. On the other hand, administration of streptozotocin decreased the number of beta cells with insulin secretory activity in comparison with intact rats, but treatment with the coriander seed extract $(200 \mathrm{mg} / \mathrm{kg})$ increased significantly the activity of the beta cells in comparison with the diabetic control rats [78].

The potential hypoglycemic activity of Coriandrum sativum (CS)-extract was investigated after a single oral dose and after daily dosing for 30 days (sub-chronic study) in normal and obese-hyperglycemichyperlipidemic $(\mathrm{OHH})$ rats. A single dose of CS-extract or GLB suppressed hyperglycemia in OHH rats, and normoglycemia was achieved at $6 \mathrm{~h}$ post dose; there was no effect on lipids, TG or insulin, but insulin resistance (IR) decreased significantly. The hypoglycemic effect was lower in normal rats. In the subchronic study in $\mathrm{OHH}$ rats, the effect of (CS-extract> glibenclamide) regarding reducing plasma glucose ( causing normoglycemia on day 21), increasing insulin and decreasing IR, TC, LDL-cholesterol, and TG. Atherosclerotic index was decreased, while cardioprotective indices were increased by CS-extract, with no effect on body weight, urea or creatinine [79].

The antihyperglycaemic properties of the aqueous extract from the leaves and stems of Coriandrum sativum were evaluated in normoglycaemic rats, and on $\alpha$-glucosidase activity from Saccharomyces cerevisiae. Rats were administered with the aqueous extract of the plant at 100,300 and $500 \mathrm{mg} / \mathrm{kg}$, to observe the effect on oral sucrose tolerance test. The aqueous extract exhibited significant antihyperglycaemic activity at the three tested doses. In vitro experiments with $\alpha$-glucosidase exhibited a competitive-type inhibition [80].

The antidiabetic and antioxidant effects of Coriandrum sativum (CS) were studied in alloxan-induced diabetic rats. The extracts of CS in alloxan-induced diabetic rats were found to significantly lower blood glucose levels. Antidiabetic activity of the CS extracts was comparable with the clinically available drug glibenclamide. The levels of serum total cholesterol, triglycerides, and low-density lipoprotein cholesterol were lower in the extracttreated group and high-density lipoprotein cholesterol was higher than the diabetic control rats. The extracts of CS exhibited strong scavenging effect on 2, 2-diphenyl-2-picrylhydrazyl free radical and inhibited lipid peroxidation. The free radical scavenging effect of the extracts was comparable with that of the reference antioxidants. Furthermore, it also showed an improved antioxidant potential as evidenced by decreased lipid peroxidation and a significant increase in the activity of various antioxidant enzymes such as catalase, superoxide dismutase, and glutathione peroxidase in the liver of diabetic rats [81].

\section{Cressa cretica}

The antidiabetic activity of Cressa cretica was evaluated in alloxan induced diabetes in rats. The maximum glucose lowering effect of (11.86\%) was observed at 12 hour after the administration of $300 \mathrm{mg} / \mathrm{Kg}$. Repeated oral treatment with ethanolic extract of Cressa cretica (EECC) $(300 \mathrm{mg} / \mathrm{Kg} / \mathrm{day})$ for two weeks significantly reduced blood glucose, serum cholesterol and improved HDL-cholesterol and albumin as compared to diabetic control group [82-83].

The antidiabetic potential of methanolic extract of Cressa cretica was studied in streptozotocin induced diabetic rats. The methanolic extract of Cressa cretica was administered orally at a dose of $100 \mathrm{mg} / \mathrm{kg}$ for 15 days to streptozotocin induced diabetic rats. Methanolic extract of Cressa cretica produced a significant reduction in fasting blood glucose level in diabetic rats. Significant differences were also observed in body weight in methnolic extract treated diabetic rats, when compared with diabetic control, normal control and standard drug treated rats. The authors postulated that phenolic compounds and flavonoids were responsible for antidiabetic activity [83-84].

\section{Crocus sativus}

The ameliorative effect of saffron aqueous extract on hyperglycemia and oxidative stress on diabetic encephalopathy was studied in streptozotocin induced diabetes mellitus in rats. Saffron at 40 and $80 \mathrm{mg} / \mathrm{kg}$ significantly increased body weight and serum TNF- $\alpha$ and decreased blood glucose levels, glycosylated serum proteins, and serum advanced glycation endproducts (AGEs) levels which triggered oxidative reaction [85-86]. 
Advanced glycation end products (AGEs) were causally correlated with diabetic vascular complications. AGEs triggered oxidative reaction then accelerated endothelial cell apoptosis which was a critical event in the process of vascular complications. Exposure of bovine endothelial cells (BEC) to $200 \mathrm{~g} / \mathrm{ml}$ AGEs for $48 \mathrm{~h}$ resulted in a significant increase in apoptotic rate, compared with control. Crocetin (a metabolite of crocin) prevented AGEsinduced BEC apoptosis, which correlates with crocetin attenuation of AGEs mediated increase of intracellular reactive oxygen species (ROS) formation and elevation of intracellular $\mathrm{Ca}^{2+}$ concentration $\left(\left[\mathrm{Ca}^{2+}\right] \mathrm{i}\right)$ level $(\mathrm{P}<$ 0.01 versus AGEs group). These results demonstrate that crocetin prevents AGEs-induced BEC apoptosis through ROS inhibition and $\left(\left[\mathrm{Ca}^{2+}\right] \mathrm{i}\right)$ stabilization and suggest that crocetin exerted a beneficial effect in preventing diabetes-associated vascular complications [86-87].

\section{Cuminum cyminum}

The orally administered seed powder $(2 \mathrm{~g} / \mathrm{kg})$ lowered the blood glucose levels in hyperglycaemic rabbits [88-89]. The Antidiabetic effects of cumin seed, was examined in streptozotocin induced diabetic rats. An eight week dietary regimen containing cumin powder $(1.25 \%)$ was found to be remarkably beneficial, as indicated by reduction in hyperglycaemia and glucosuria. This was also accompanied by improvement in body weights of diabetic animals. Dietary cumin also countered other metabolic alterations as revealed by lowered blood urea level and reduced excretions of urea and creatinine by diabetic animals [89-90].

Cuminaldehyde and cuminol were identified as potent insulinotrophic components. Cuminaldehyde and cuminol $(25 \mu \mathrm{g} / \mathrm{ml})$ showed 3.34- and 3.85-fold increased insulin secretion, respectively. The insulinotrophic action of both components was glucose-dependent and due to the closure of the ATP-sensitive $\mathrm{K}\left(\mathrm{K}^{+}-\mathrm{ATP}\right)$ channel and the increase in intracellular $\mathrm{Ca}^{2+}$ concentration. An inhibitor of insulin secretion with potent $\beta$-cell protective action was also isolated from the same petroleum ether fraction. The authors concluded that Cuminum cyminum was able to lower blood glucose without causing hypoglycaemia or $\beta$-cell burn out [91].

The effect of methanolic extract of seeds of Cuminum cyminum (CC) on diabetes, oxidative stress and formation of advanced glycated end products (AGE) were investigated compared with glibenclamide. In vitro studies indicated that $\mathrm{CC}$ inhibited free radicals and AGE formation. Treatment of streptozotocin-diabetic rats with $\mathrm{CC}$ and glibenclamide for 28 days induced a reduction in blood glucose, glycosylated hemoglobin, creatinine, blood urea nitrogen and improved serum insulin and glycogen (liver and skeletal muscle) content when compared to diabetic control rats. Significant reductions in renal oxidative stress and AGE were observed with CC when compared to diabetic control and glibenclamide. CC and glibenclamide also improved antioxidant status in kidney and pancreas of diabetic rats. Diabetic rats showed increase in rat tail tendon collagen, glycated collagen, collagen linked fluorescence and reduction in pepsin digestion [92].

The role of Cuminum cyminum supplementation on the plasma and tissue lipids was studied in alloxan diabetic rats. Oral administration of $0.25 \mathrm{~g} / \mathrm{kg}$ body weight of Cuminum cyminum for 6 weeks to diabetic rats resulted in significant reduction in blood glucose and an increase in total haemoglobin and glycosylated haemoglobin. It also prevented a decrease in body weight. Cuminum cyminum treatment also resulted in a significant reduction in plasma and tissue cholesterol, phospholipids, free fatty acids and triglycerides. Histological observations demonstrated significant fatty changes and inflammatory cell infiltrates in diabetic rat pancreas, but supplementation with Cuminum cyminum to diabetic rats significantly reduced the fatty changes and inflammatory cell infiltrates. Moreover, Cuminum cyminum supplementation was found to be more effective than glibenclamide in the treatment of diabetes mellitus [93].

\section{Cydonia oblonga}

The antidiabetic activity of quince leaves hydro-ethanolic extract was studied in normal and streptozocin-induced diabetic rats. There was no significant effect on normal rats glucose, while, a significant reduction in the blood glucose levels was recorded in diabetic rats at a time period of 0 to $3 \mathrm{~h} \mathrm{[94-95].}$

\section{Cynodon dactylon}

The antidiabetic effect of ethyl acetate (70\%) extract of Cynodon dactylon root and stem, was investigated in diabetes induced by a combination of ketamine $(60 \mathrm{mg} / \mathrm{Kg})$ and xylazine $(10 \mathrm{mg} / \mathrm{Kg})$ in mice, which induced a sustained hyperglycemia. Mice were treated with 50 and 100mg/Kg Cynodon dactylon extract. Both dosages of Cynodon dactylon extract had significant lowering effect on blood glucose level. The first dose was more effective than the second, and its impact was just like insulin [96].

250,500 and $1000 \mathrm{mg} / \mathrm{kg}$ bw of aqueous extract of Cynodon dactylon were evaluated in diabetic rats and the dose of $500 \mathrm{mg} / \mathrm{kg}$ orally was the most effective dose. It lowered blood glucose level around $31 \%$ after $4 \mathrm{~h}$ of administration in normal rats [97-98].

Aqueous and non-polysaccharide fraction of Cynodon dactylon exhibited significant antihyperglycaemic activity in diabetic rats and decreased the glucose, cholesterol, triglyceride, high density lipoprotein, low density lipoprotein and urea levels [99]. 
The the antidiabetic activity of ethanolic extract of Cynodon dactylon root stalks was evaluated in streptozotocin induced diabetic rats. The study showed that the anti diabetic activity of ethanolic extract $(500 \mathrm{mg} / \mathrm{kg})$ of Cynodon dactylon root stalks was comparable with the standard drug, tolbutamide [100].

The antidiabetic activity of aqueous Cynodon dactylon extracts was evaluated through an extensive in silico docking approach with PPAR $\gamma$ (Peroxisome Proliferator-Activated Receptor), GLUT-4 (glucose transporter-4) and SGLT2 (sodium glucose co-transporter-2). Interactions of these molecules with Gln 295 and Asp 294 residues of SGLT2 have been shown to compare well with that of the phase III drug, dapagliflozin. These residues have been proven to be responsible for sugar sensing and transport. This work showed that Cynodon dactylon extract was a potential SGLT2 inhibitor for diabetic neuropathy [101].

The antidiabetic, antioxidant and hypolipidemic efficacy of Cynodon dactylon were studied in alloxaninduced diabetic rats. A significant diminution of fasting blood sugar level with a significant increase in HDL and decrease $(\mathrm{p}<0.05)$ in cholesterol, triglyceride, LDL and VLDL were recorded after 15 days of treatment with $450 \mathrm{mg} / \mathrm{kg}$ bw Cynodon dactylon leaves extract. The investigation also revealed that the activities of AST, ALT, ALP, AP, LDH, and CPK were significantely $(\mathrm{p}<0.05)$ decreased in the extract- supplemented group. In the diabetic rats, the significant decrease in protein content and SOD, CAT, GPx, and GSH (p<0.05) activity and increase in LPO in plasma were found to be ameliorated after treatment with the plant extract [102].

The ability of the secondary metabolites of Cynodon dactylon to serve as an antagonist to angiotensin II type 1 receptor $\left(\mathrm{AT}_{1}\right)$ was studied. Twenty-four compounds were identified as the secondary metabolites of hydroalcoholic extract of Cynodon dactylon using the GCMS technique. Sixteen ligands showed effective binding with the target protein; diazoprogesteron, didodecyl phthalate, and 9,12-octadecadienoyl chloride and can be considered as compounds that could be used to bind with the active site sequence of $\mathrm{AT}_{1}$. The authors concluded, that the metabolites of Cynodon dactylon could serve as a natural antagonist to $\mathrm{AT}_{1}$ that could be used to treat diabetic retinopathy, so, activation of $\mathrm{AT}_{1}$ expressed on retinal endothelial cells and pericytes has been implicated in contributing to the microvascular abnormalities in diabetic retinopathy [103].

\section{Cyperus rotuntdus}

The antidiabetic effect of of Cyperus rotundus was evaluated on alloxan induced hyperglycemia in rats. Oral daily administration of $500 \mathrm{mg} / \mathrm{kg}$ of the extract once a day for seven consecutive days, significantly lowered the blood glucose levels [104].

Cyperus rotundus $(2.5 \mathrm{ml} / \mathrm{kg}$, orally of $10 \%$ of the aqueous decoction of tuber parts) significantly decreased fasting serum glucose level in alloxan induced diabetic and normoglycemic rabbits. Hypoglycemic effects was appeared from the first week of the treatment, and tended to be increased with the continuation of the treatment [105].

The preventive role of ethanolic extract of Cyperus rotundus rhizomes (CRRE) was investigated on age associated changes in glucose in young and aged rats. CRRE was given as $(500 \mathrm{mg} / \mathrm{kg}$ bw) orally for 30 days. Age associated increase in serum glucose was observed in aged rats compared to young rats. Administration of CRRE to aged rats prevented the age associated changes in glucose level [106].

\section{CONCLUSION}

The paper reviewed the antidiabetic effects of some medicinal plants to know their effectiveness and safety when they are used in medical practice.

\section{REFERENCES}

[1] Al-Snafi AE. Therapeutic properties of medicinal plants: a review of plants with antidiabetic effects (part 1). J of Pharmaceutical Biology 2015; 5(3): 218-229.

[2] Al-Snafi AE. Clinically tested medicinal plant: A review (Part 1). SMU Medical Journal 2016; 3(1): 99 128.

[3] Al-Snafi AE. Chemical constituents and pharmacological activities of Milfoil (Achillea santolina) - A Review. Int J Pharm Tech Res 2013, 5(3): 1373-1377.

[4] Al-Snafi AE. The chemical constituents and pharmacological effects of Adiantum capillus-veneris - A review. Asian Journal of Pharmaceutical Science and Technology 2015; 5(2): 106-111.

[5] Al-Snafi AE. The pharmacological and therapeutic importance of Agrimonia eupatoria- A review. Asian Journal of Pharmaceutical Science and Technology 2015; 5(2): 112-117.

[6] Al-Snafi AE. Chemical constituents and pharmacological importance of Agropyron repens - A review. Research Journal of Pharmacology and Toxicology 2015; 1 (2): 37-41.

[7] Al-Snafi AE. Pharmacological effects of Allium species grown in Iraq. An overview. International Journal of Pharmaceutical and health care Research 2013;1(4):132-147.

[8] Al-Snafi AE. The pharmacological importance of Aloe vera- A review. International Journal of Phytopharmacy Research 2015; 6(1) : 28-33. 
[9] Al-Snafi AE. The pharmacological activities of Alpinia galangal - A review. International Journal for Pharmaceutical Research Scholars 2014; 3(1-1): 607-614.

[10] Al-Snafi AE. The Pharmaceutical importance of Althaea officinalis and Althaea rosea: A Review. Int J Pharm Tech Res 2013; 5(3):1387-1385.

[11] Al-Snafi AE. The pharmacology of Anchusa italica and Anchusa strigosa - A review. International Journal of Pharmacy and Pharmaceutical Sciences 2014; 6(4): 7-10.

[12] Al-Snafi AE. Medical importance of Anthemis nobilis ( Chamaemelum nobilis)- A review. Asian Journal of Pharmaceutical Science \& Technology 2016; 6(2): 89-95.

[13] -Al-Snafi AE. The Pharmacological importance and chemical constituents of Arctium Lappa. A review. International Journal for Pharmaceutical Research Scholars 2014; 3(1-1): 663-670.

[14] Al-Snafi AE. The pharmacological importance of Artemisia campestris- A review. Asian Journal of Pharmaceutical Research 2015;5(2): 88-92.

[15] Al-Snafi AE. The pharmacological importance of Asparagus officinalis - A review. Journal of Pharmaceutical Biology 2015; 5(2): 93-98.

[16] Al-Snafi AE. The nutritional and therapeutic importance of Avena sativa - An Overview. International Journal of Phytotherapy 2015; 5(1): 48-56.

[17] Al-Snafi AE. The Pharmacological Importance of Ballota nigra -A review. Ind J of Pharm Sci \& Res 2015; 5(4): 249-256.

[18] Al-Snafi AE. The Pharmacological Importance of Benincasa hispida. A review. Int Journal of Pharma Sciences and Research 2013; 4(12): 165-170.

[19] Al-Snafi AE. The pharmacological importance of Brassica nigra and Brassica rapa grown in Iraq. J of Pharm Biology 2015; 5(4): 240-253.

[20] Al-Snafi AE. The Chemical constituents and pharmacological effects of Bryophyllum calycinum. A review. Journal of Pharma Sciences and Research 2013; 4(12): 171-176.

[21] Al-Snafi AE. Pharmacology and medicinal properties of Caesalpinia crista - An overview. International Journal of Pharmacy 2015; 5(2): 71-83.

[22] Al-Snafi AE. The constituents and pharmacological properties of Calotropis procera - An Overview. International Journal of Pharmacy Review \& Research 2015; 5(3): 259-275.

[23] Al-Snafi AE. Bioactive components and pharmacological effects of Canna indica- An Overview. International Journal of Pharmacology and toxicology 2015; 5(2):71-75.

[24] Al-Snafi AE. The chemical constituents and pharmacological effects of Capparis spinosa - An overview. Indian Journal of Pharmaceutical Science and Research 2015; 5(2): 93-100.

[25] Al-Snafi AE. The pharmacological importance of Capsicum species (Capsicum annuum and Capsicum frutescens) grown in Iraq. Journal of Pharmaceutical Biology 2015; 5(3): 124-142.

[26] Al-Snafi AE. The chemical constituents and pharmacological importance of Carthamus tinctorius - An overview. Journal of Pharmaceutical Biology 2015; 5(3): 143-166.

[27] Al-Snafi AE. The chemical constituents and pharmacological effects of Carum carvi - A review. Indian Journal of Pharmaceutical Science and Research 2015; 5(2): 72-82.

[28] Al-Snafi AE. The therapeutic importance of Cassia occidentalis - An overview. Indian Journal of Pharmaceutical Science \& Research 2015; 5 (3): 158-171.

[29] Al-Snafi AE. The pharmacological importance of Casuarina equisetifolia - An Overview. International Journal of Pharmacological Screening Methods 2015; 5(1): 4-9.

[30] Yadav BV, Deshmukh TA, Badole SL, Kadam HM, Bodhankar SL and Dhaneshwar SR. Antihyperglycemic activity of Cicer arietinum seeds. Pharmacologyonline 2009; 3: 748-757.

[31] Ahmed $\mathrm{N}$ and Tarannum S. Acetylcholinesterase activity in the brain of alloxan diabetic albino rats: Presence of an inhibitor of this enzyme activity in the cerebral extract. Int $J$ Diabetes Dev Ctries 2009;29(4):174-177.

[32] Al-Snafi AE. The medical Importance of Cicer arietinum - A review IOSR Journal of Pharmacy 2016; 6(3): 29-40.

[33] Pushparaj PN, Low HK, Manikandan J, Tan BK and Tan CH. Anti-diabetic effects of Cichorium intybus in streptozotocin-induced diabetic rats. J Ethnopharmacol 2007; 111(2):430-434.

[34] Muthusamy VS, Anand S, Sangeetha KN, Sujatha S, Arun B and Lakshmi BS. Tannins present in Cichorium intybus enhance glucose uptake and inhibit adipogenesis in 3T3-L1 adipocytes through PTP1B inhibition. Chem Biol Interact 2008;174(1):69-78.

[35] Kim M and Shin HK. The water-soluble extract of chicory reduces glucose uptake from the perfused jejunum in rats. J Nutr 1996;126(9):2236-2242.

[36] Azay-Milhau J, Ferrare K, Leroy J, Aubaterre J, Tournier M, Lajoix AD and Tousch D. Antihyperglycemic effect of a natural chicoric acid extract of chicory (Cichorium intybus L.): a comparative in vitro study with the effects of caffeic and ferulic acids. J Ethnopharmacol 2013;150(2):755-760. 
[37] Jurgoński A, Juśkiewicz J, Zduńczyk Z and Król B. Caffeoylquinic acid-rich extract from chicory seeds improves glycemia, atherogenic index, and antioxidant status in rats. Nutrition 2012; 28(3):300-306.

[38] Yunyan G, Bing Z, Peifen J, et al. Research on the pharmacological activities of chicory alcohol soluble and alcohol deposit extracts. J Beijing University of Traditional Chinese medicine 1999; 22(3): 43-44.

[39] Minaiyan M, Ghannadi AR, Mahzouni P and Abed AR. Preventive effect of Cichorium intybus L. two extracts on cerulein-induced acute pancreatitisin mice. Int J Prev Med 2012;3(5):351-357.

[40] Xiong WT, Gu L, Wang C, Sun HX and Liu X. Anti-hyperglycemic and hypolipidemic effects of Cistanche tubulosa in type 2 diabetic $d b / d b$ mice. Journal of Ethnopharmacology 2013; 150(3): 935-945.

[41] Morikawa T, Ninomiya K, Imamura M, Akaki J, Fujikura S, Pan Y, Yuan D, Yoshikawa M, Jia X, Li Z and Muraoka O. Acylated phenylethanoid glycosides, echinacoside and acteoside from Cistanche tubulosa, improve glucose tolerance in mice. J Nat Med 2014;68(3):561-566.

[42] Huseini H, Darvishzadeh F, Heshmat R, Jafariazar Z, Raza M and Larijani B. The clinical investigation of Citrullus colocynthis (L.) Schrad fruit in treatment of Type II diabetic patients: a randomized, double blind, placebo-controlled clinical trial. Phytotherapy Research 2009; 23(8): 1186-1189.

[43] Al-snafi AE. Chemical constituents and pharmacological effects of Citrullus colocynthis - A review. IOSR Journal of Pharmacy 2016; 6(3): 57-67.

[44] Benariba N, Djaziri R, Hupkens E, Louchami K, Malaisse WJ and Sener A. Insulinotropic action of Citrullus colocynthis seed extracts in rat pancreatic islets. Mol Med Rep 2013;7(1):233-236.

[45] Atole SK, Jangde CR, Philip P, Rekhe DS, Aghav DV, Waghode HJ and Chougule AM. Safety evaluation studies of Citrullus colocynthis for diabetes in rats. Veterinary World 2009;2(11):423-425.

[46] Agarwal V, Sharma AK, Upadhyay A, Singh G and Gupta R. Hypoglycemic effects of Citrullus colocynthis roots. Acta Poloniae Pharmaceutica- Drug Research 2012; 69(1):75-79.

[47] Gurudeeban S and Ramanathan T. Antidiabetic effect of Citrullus colocynthis in alloxan-induced diabetic rats. Ethnopharmacology 2010; 1(1): 112-1115.

[48] Heydari M, Homayouni K, Hashempur MH and Shams M. Topical Citrullus colocynthis in painful diabetic neuropathy: a double-blind randomized placebo-controlled clinical trial. J Diabetes 2015; doi: 10.1111/1753-0407.12287.

[49] Khalil M, Mohamed G, Dallak M, Al-Hashem F, Sakr H, Eid RA, Adly MA, Al-Khateeb M, Banihani $\mathrm{S}$, Hassan $\mathrm{Z}$ and Bashir N. The effect of Citrullus colocynthis pulp extract on the liver of diabetic rats a light and scanning electron microscopic study. American Journal of Biochemistry and Biotechnology 2010; 6(3): 155-163.

[50] Akhila S, Bindu AR, Bindu K and Aleykutty NA. Phytochemical and pharmacological evaluation of Citrus limon pell. World Journal of Pharmacy and Pharmaceutical Sciences 2015; 4(3): 1128-1135.

[51] Ahmad M, Ansari MN, Alam A and Khan TH. Oral dose of citrus peel extracts promotes wound repair in diabetic rats. Pak J Biol Sci 2013;16(20):1086-1094.

[52] Menichini F, Tundis R, Loizzo MR, Bonesi M, Liu B, Jones P, Persaud SJ, Mastellone V, Lombardi P, Houghton PJ, Avallone L and Menichini F. C. medica cv Diamante peel chemical composition and influence on glucose homeostasis and metabolic parameters. Food Chemistry 2011; 124(3): 1083-1089.

[53] Sah AN, Josh A, Juyal V and Kumar T. Antidiabetic and hypolipidemic activity of Citrus medica Linn. seed extract in streptozotocin induced diabetic rats. Pharmacognosy Journal 2011;3(23): 80-84.

[54] Peng CH, Ker YB, Weng CF, Peng CC, Huang CN, Lin LY and Peng RY. Insulin secretagogue bioactivity of finger citron fruit (Citrus medica L. var. Sarcodactylis Hort, Rutaceae). J Agric Food Chem 2009;57(19):8812-8819.

[55] KunduSen S, Haldar PK, Gupta M, Mazumder UK, Saha P, Bala A, Bhattacharya S and Kar B. Evaluation of antihyperglycemic activity of Citrus limetta fruit peel in streptozotocin-induced diabetic rats. ISRN Endocrinol 2011; doi: 10.5402/2011/ 869273.

[56] Padilla-Camberos E, Lazcano-Díaz E, Flores-Fernandez JM, Owolabi MS, Allen K and VillanuevaRodríguez S. Evaluation of the inhibition of carbohydrate hydrolyzing enzymes, the antioxidant activity, and the polyphenolic content of Citrus limetta peel extract. Scientific World Journal 2014; 2014: 121760. doi: 10.1155/ 2014/121760.

[57] Parmar HS and Kar A. Medicinal values of fruit peels from Citrus sinensis, Punica granatum and Musa paradisiacal with respect to alterations in tissue lipid peroxidation and serum concentration of glucose, insulin and thyroid hormones. J Med Food 2008; 11: 376-381.

[58] Parmar HS and Kar A. Possible amelioration of atherogenic diet induced dyslipidemia, hypothyroidism and hyperglycemia by the peel extracts of Mangifera indica, Cucumis melo and Citrullus vulgaris fruits in rats and liver antioxidative enzyme avtivity in rats. Biosci Biotect Biochem 1995; 59: 595-601.

[59] Parmar HS and Kar A. Antidiabetic potential of Citrus sinensis and Punica granatum peel extracts in alloxan treated male mice. Biofactors 2007;31(1):17-24.

[60] Rajeev P, Kumar YS and Gupta SK. Anti-diabetic activity of Clerodendrum (or Clerodendron) inerme using in vivo and in vitro studies, novel science. Int J Pharm Sci 2012;1(6): 298-302. 
[61] Al-Snafi AE. Chemical constituents and pharmacological effects of Clerodendrum inerme- A review. SMU Medical Journal 2016; 3(1): 129-153.

[62] Al-Snafi AE. Pharmacological importance of Clitoria ternatea - A review IOSR Journal of Pharmacy 2016; 6(3): 68-83.

[63] Abhishek S, Vikas S, Minu K and Pankaj M. Comparative hypoglycemic effects of different extract of Clitoria ternatea leaves on rats. IOSR Journal of Pharmacy and Biological Sciences 2015; 10(2-III): 6065.

[64] Abhishek S, Pankaj M and Vikas S. Hypoglycemic effects of Clitoria ternatea leaves (Linn) Extract. Journal of Pharmacology and Toxicological Studies 2013; 1(1): 4-7.

[65] Daisy P, Santosh S and Rajathi M. Antihyperglycemic and antihyperlipidemic effects of Clitoria ternatea Linn. in alloxan-induced diabetic rats. African Journal of Microbiology Research 2009; 3 (5): 287-291.

[66] Daisy P and Rajathi M. Hypoglycemic effects of Clitoria ternatea Linn. Tropical Journal of Pharmaceutical Research 2009; 8 (5): 393-398.

[67] Kavitha $\mathrm{R}$ and Premalakshmi V. Studies on the synergetic effect of Trichosanthes dioica and Clitoria ternatea leaf extract on the streptozotocin-induced diabetic rats. International Journal of Research in Pharmaceutical and Biomedical Sciences 2012; 3(3): 1056-1064.

[68] Mathada RV, Jevoor PS and Ravishankar R. Effect of Clitoria ternatea Linn plant root extract on the hippocampal area $\mathrm{Ca} 3$ and pancreas of juvenile diabetic rats- A preliminary investigation. Spatula DD 2012; 2(1): 9-16.

[69] Ravishankar MV and Rohini HN. Effect of Clitoria ternatea Linn plant root extract on the neuron of frontal cortex and dentate gyrus of young diabetic rats- A preliminary investigation. The Experiment 2013; 16(4): 1138-1144.

[70] Chayaratanasin P, Barbieri MA, Suanpairintr N and Adisakwattana S. Inhibitory effect of Clitoria ternatea flower petal extract on fructose-induced protein glycation and oxidation-dependent damages to albumin in vitro. BMC Complement Altern Med 2015;15:27.

[71] Verma PR, Itankar PR and Arora SK. Evaluation of antidiabetic antihyperlipidemic and pancreatic regeneration, potential of aerial parts of Clitoria ternatea. Rev Bras Farmacogn 2013; 23: 819-829.

[72] Rajeshwari CU and Andallu B. Oxidative stress in NIDDM patients: influence of coriander (Coriandrum sativum) seeds. Research Journal of Pharmaceutical, Biological and Chemical Sciences 2011; 2(1): 31-41.

[73] -Waheed A, Miana GA, Ahmad SI and Khan MA. Clinical investigation of hypoglycemic effect of Coriandrum sativum in type-2 (NIDDM) diabetic patients. Pakistan Journal of Pharmacology 2006; 23(1): $7-11$.

[74] Naquvi KJ, Ali M and Ahamad J. Antidiabetic activity of aqueous extract of Coriandrum sativum L. fruits in streptozotocin induced rats. Int J Pharm Pharm Sci 2012; 4 ( Suppl 1): 239-240.

[75] Mazhar J and Mazumder A. Evaluation of antidiabetic activity of methanolic leaf extract of Coriandrum sativum in alloxan induced diabetic rats. Research Journal of Pharmaceutical, Biological and Chemical Sciences 2013; 3(4): 500-507.

[76] Gray AM and Flatt PR. Insulin-releasing and insulin-like activity of the traditional anti-diabetic plant Coriandrum sativum (coriander). Br J Nutr 1999;81(3):203-209.

[77] Patel DK, Desal SN, Devkar RV and Ramachandran AV. Coriandrum sativum L. aqueous extract mitigates high fat diet induced insulin resistance by controlling visceral adiposity. Boletín Latinoamericano y del Caribe de Plantas Medicinales y Aromáticas 2011; 10(2): 127-135.

[78] Eidi M, Eidi A, Saeidi A, Molanaei S, Sadeghipour A, Bahar M and Bahar K. Effect of coriander seed (Coriandrum sativum L.) ethanol extract on insulin release from pancreatic beta cells in streptozotocininduced diabetic rats. Phytother Res 2009; 23(3): 404-406.

[79] Aissaoui A, Zizi S, Israili ZH and Lyoussi B. Hypoglycemic and hypolipidemic effects of Coriandrum sativum L. in Meriones shawi rats. J Ethnopharmacol 2011; 137(1): 652-661.

[80] Brindis F, González-Andrade M, González-Trujano ME, Estrada-Soto S and Villalobos-Molina R. Postprandial glycaemia and inhibition of $\alpha$-glucosidase activity by aqueous extract from Coriandrum sativum. Nat Prod Res 2014; 28(22): 2021-2025.

[81] Sreelatha S and Inbavalli R. Antioxidant, antihyperglycemic, and antihyperlipidemic effects of Coriandrum sativum leaf and stem in alloxan-induced diabetic rats. J Food Sci 2012;77(7):T119-123.

[82] Chaudhary S, Khosa RL, Jha KK and Verma N. Evaluation of Antidiabetic activity of Cressa cretica Linn in alloxan induced diabetes in rats. Pharmacologyonline 2010; 3: 181-188.

[83] Al-Snafi AE. The chemical constituents and therapeutic importance of Cressa cretica- A review . IOSR Journal of Pharmacy 2016; 6(6): 39-46.

[84] Verma N, Jha KK, Chaudhary S, Garg V, Ahmad S and Kumar U. Assessment of antidiabetic potential of Cressa cretica Linn in streptozotocin-induced diabetic rats. International Journal of Advance Research and Innovation 2014; 2(1): 181-184. 
[85] Samarghandian S, Azimi-Nezhad M and Samini F. Ameliorative effect of saffron aqueous extract on hyperglycemia, hyperlipidemia, and oxidative stress on diabetic encephalopathy in streptozotocin induced experimental diabetes mellitus. Biomed Res Int. 2014; doi: 10.1155/2014/920857.

[86] Al-Snafi AE. The pharmacology of Crocus sativus- A review. IOSR Journal of Pharmacy 2016; 6(6): 838.

[87] Xiang M, Yang M, Chenghua Z, Juan L, Wenna L and Zhiyu Q. Crocetin prevents AGEs-induced vascular endothelial cell apoptosis. Pharmacological research 2006; 54: 268-274.

[88] Jain SC, Purohit M and Jain R. Pharmacological evaluation of Cuminum cyminum. Fitoterapia 1992; 63(4): 291-294.

[89] Al-Snafi AE. The pharmacological activities of Cuminum cyminum - A review. IOSR Journal of Pharmacy 2016; 6(6): 46-65.

[90] Willatgamuva SA, Platel K, Sarawathi G and Srinivasan K. Antidiabetic influence of dietary cumin seeds (Cuminum cyminum) in streptozotocin induced diabetic rats. Nutr Res 1998; 18:131-42.

[91] Patil SB, Takalikar SS, Joglekar MM, Haldavnekar VS and Arvindekar AU. Insulinotropic and $\beta$-cell protective action of cuminaldehyde, cuminol and an inhibitor isolated from Cuminum cyminum in streptozotocin-induced diabetic rats. Br J Nutr 2013; 110(8):1434-1443.

[92] Jagtap AG and Patil PB. Antihyperglycemic activity and inhibition of advanced glycation end product formation by Cuminum cyminum in streptozotocin induced diabetic rats. Food Chem Toxicol 2010; 48(89): 2030-2036.

[93] Dhandapani S, Subramanian VR, Rajagopal S and Namasivayam N. Hypolipidemic effect of Cuminum cyminum L. on alloxan-induced diabetic rats. Pharmacol Res 2002; 46(3): 251-255.

[94] Aslan M, Orhan N, Orhan DD and Ergun F. Hypoglycemic activity and antioxidant potential of some medicinal plants traditionally used in Turkey for diabetes. J Ethnopharmacol 2010; 128: 384-389.

[95] Al-Snafi AE. The medical importance of Cydonia oblonga- A review. IOSR Journal of Pharmacy 2016; 6(6): 87-99.

[96] Nafisi S, Nezhady MA and Asghari MH. Comparative and mixture effect of Cynodon dactylon, electromagnetic field and insulin on diabetic mouse. Balkan Med J 2012; 29(4): 345-348.

[97] Rai PK, Jaiswal D, Rai DK, Sharma B and Watal G. Antioxidant potential of oral feeding of Cynodon dactylon extract on diabetes-induced oxidative stress. J Food Biochem 2010; 34: 78-92.

[98] Singh SK, Kesari AN, Gupta RK, Jaiswal D and Watal G. Assessment of antidiabetic potential of Cynodon dactylon extract in streptozotocin diabetic rats. J Ethnopharmacol 2007; 114(2): 174-179.

[99] Jarald EE, Joshi SB and Jain DC. Antidiabetic activity of aqueous extract and non-polysaccharide fraction of Cynodon dactylon Pers. Indian J Exp Biol 2008; 46(9): 660-667.

[100] Kumar AS, Gnananath K, Kiran D, Reddy AM and Raju Ch. Antidiabetic activity of ethanolic extract of Cynodon dactylon root stalks in streptozotocin induced diabetic rats. International Journal of Advances in Pharmaceutical Research 2011; 2(8): 418-422.

[101] Annapurna HV, Apoorva B, Ravichandran N, Purushothaman K, Brindha P, Swaminathan $\mathrm{S}$, Vijayalakshmi $\mathrm{M}$ and Nagarajan A. Isolation and in silico evaluation of antidiabetic molecules of Cynodon dactylon (L). Journal of Molecular Graphics and Modelling 2013; 39: 87-97.

[102] Karthik D and Ravikumar S. A study on the protective effect of Cynodon dactylon leaves extract in diabetic rats. Biomed Environ Sci 2011; 24(2): 190-199.

[103] -Jananie RK, Priya V and Vijayalakshmi K. Secondary metabolites of Cynodon dactylon as an antagonist to angiotensin II type1 receptor: Novel in silico drug targeting approach for diabetic retinopathy. J Pharmacol Pharmacother 2012; 3(1):20-25.

[104] Raut NA and Gaikwad NJ. Antidiabetic activity of hydro-ethanolic extract of Cyperus rotundus in alloxan induced diabetes in rats. Fitoterapia 2006; 77: 585-588.

[105] Al-Snafi AE, Al-Trikrity AH. and Ahmad RH. Hypoglycemic effect of Teucrium polium and Cyperus rotundus in normal and diabetic rabbits. Med J Tikrit Univ 2013; 9(2): 1-10.

[106] Nagulendran KR, Mahesh R and Begum VH, Preventive role of Cyperus rotundus rhizomes extract on age associated changes in glucose and lipids, Pharmacologyonline 2007; 2: 318-325. 